\title{
すべり摩擦型振動の応答解析手法に関する研究 STUDY ON VIBRATION ANALYSIS METHOD OF SLIDING FRICTION TYPE
}

\author{
高橋亜佑美*, 内田基城*, 境＼cjkstart孝祐**, 柴田耕 - *** \\ Ayumi TAKAHASHI, Motoki UCHIDA, Takasuke SAKAI \\ and Kouichi SHIBATA
}

\begin{abstract}
Vibration systems with sliding friction are analyzed by using the Linear Accelerated Method based upon a new analytical logic which can study in detail the state of sliding motion within the constant time step. The logic was applied to linear single-mass systems with and without external force. The obtained numerical values are compared with the theoretical one and also the one without this logic. Then it was proved that the computing time is shortened greatly. In other words, much shorter time step is demanded, if the same computing accuracy is expected without the new logic.

It is also shown that the new logic is applicable to linear two-mass systems and non-linear vibration systems in which the upper part is a non-linear structure and the lower part is a sliding friction.
\end{abstract}

Keywords: vibration response, sliding friction, linear acceleration method, two-mass systems 振動応答, すべり摩擦, 線形加速度法, 2 質点系

\section{1. 序論}

本論はす心゙り摩擦を持つ振動系の数值解析手法について追究した ものである。すなわち、簡単な系において、すべり摩擦型振動系の 数值解析と理論解等を比較することで手法の妥当性を検証し、より 複雑な系への応用と解析手法の構築を目指して研究を行った。

すべり摩擦型免震システムの研究では、FAF(フリーアクセスフロ ア）1（1987 年)や建築物用積層ゴムとの組み合わせ等の研究が行わ れている。またその解析手法も、1 質点系において理論解の導出お よび、多質点系に対しての応答解析など様々な研究 2),33が行われて いる。

我々の研究はこれまで、すべり摩擦型免震に関する基礎的研究 4),5) (1990 年)として過去に得られた地震波による各種地震応答解析か ら、免震構造の応答值の最小值を示寸固有周期や摩擦係数の最適值 を求めることができた。さらに、上部は構造物、下部はすべり摩擦 と寸る 2 質点系のすべり摩擦支承の実用方法を提案し、FAFに対し、 す心゙り支承を組み合わせた振動台上実験結果 ${ }^{5}$ )から、解析手法の有 効性を示した。次に、既に乾燥状態で低摩擦係数が得られる無潤滑 材料の中から下部摩擦材と上部摩擦材の組み合わせにより振動実験 を行い、動的摩擦特性を検討した $\left.{ }^{6}\right)(1991$ 年)。さらに、摩擦係数 の速度依存性、面圧依存性に注目し、より精度の高いシミュレーショ ンが可能となった ${ }^{7)}(2001$ 年)。同時に、摩擦係数変動型のシステム の解析が初めて可能となった。

我々はすべり現象を物理的に捉え、短い刻み時間内における運動
状態を分類、状態毎に計算処理を行うことにより、すべり現象のシ ミュレーション手法を構築し、比較実験を行うことでその手法の有 効性を立証してきた 4),5),7)。これによりすべり摩擦型免震システムの 課題である残留変位や実地震波に対する挙動を容易に確認できるよ うになった。また、運動状態を分類し計算処理を行うため、摩擦係 数の速度依存性、面圧依存性などの影響を簡単に反映することも可 能となった。

一方すべり摩擦がある振動系では、速度が符号を変えるとき、忘 答加速度が不連続に変化する。このことが数值計算をする場合、計 算処理を難しくしている。一つの処理方法は、刻み時間を細分化す ることであるが、計算時間は増大してしまう。

そこで本論では、刻み時間を細分化せずに、刻み時間内での運動 状態を分類、検討する処理方法を提案し、その処理方法について追 求した。

すでに、簡単には文献 1) にも示されているが、ここであらためて 線形加速度法でさらに詳細に計算方法を展開し、理論解及び他手法 と比較し、本手法の妥当性を示した。

初めに、新たに提案する運動状態の分類による計算処理方法につ いて説明する。そしてす心゙り摩擦を持つ 1 質点系に、初期変位を与 えた場合の自由振動及び正弦波入力の理論解に対して、応答解析結 果を比較し提案手法の妥当性を検証する。そして 1 質点系及び 2 質 点系に正弦波、地震波入力を与えた場合の応答解析結果を示した。 数值解析手法には、例えばルンゲ・クッタ・ギル法、平均加速度法

\footnotetext{
* 日本大学大学院生産工学研究科数理情報工学専攻 大学院生

** 元 日本大学生産工学部 教授·理博

*** 日本大学生产工学部数理情報工学科 教授. 工博

Graduate Student, Dept. of Mathematical Information Engineering, College of Industrial Technology, Nihon Univ.

Former Prof., College of Industrial Technology, Nihon Univ., Dr. Sci.

Prof., Dept. of Mathematical Information Engineering, College of Industrial Technology, Nihon Univ., Dr. Eng.
} 
等あるが、計算精度並びに論理構成の容易さを考慮し、ここでは線 形加速度法を中心に述心゙、提案手法の有効性を確認寸る。さらに 2 質点非線形モデルに対しても応答解析が可能であることも示す。

\section{2. すべり摩擦を持つ 1 質点系の運動方程式}

質点に摩擦力、バネの復元力、速度に比例する粘性抵抗が作用す る系(図 1)に強制外力が加わる場合の運動方程式を以下のように示 す。
（）す）ずりが生じていない場合$$
x=\text { constant } \quad, \quad \dot{x}=0
$$

（II）す心゙りが生じている場合

$$
\left.\begin{array}{c}
m(\ddot{x}+\ddot{y})+c \dot{x}+k x+\gamma_{1} \operatorname{sgn}(\dot{x})=0 \\
\gamma_{1}=\mu m g \\
\dot{x}>0 \rightarrow \operatorname{sgn}(\dot{x})=+1 \\
\dot{x}<0 \rightarrow \operatorname{sgn}(\dot{x})=-1
\end{array}\right\}
$$

（I）、（II）の切りかえ条件は、応答速度が 0 の時に、以下の式を満 たすとき質点はすべり、それ以外は静止とする。

$$
|m \ddot{y}+c \dot{x}+k x|>\gamma_{1}
$$

質点のすべり現象の場合分けに関しては、他手法と提案手法を下記 で述べる。この運動方程式を線形加速度法により解析した。

$(x$ : 相対変位, $\dot{x}:$ 相対速度, $\ddot{x}:$ 相対加速度, $y$ : 入力変位, $\ddot{y}$ ： 入力加速度, $m$ : 質量, $c$ : 減衰係数, $k$ : ばね剛性, $g$ : 重力加 速度, $\gamma_{1}$ : クーロン摩擦力, $\mu$ : 摩擦係数（本論は静止摩擦係数 動摩擦係数は区別しない。摩擦係数変動型については、今後の研究 で取り入れていく。)

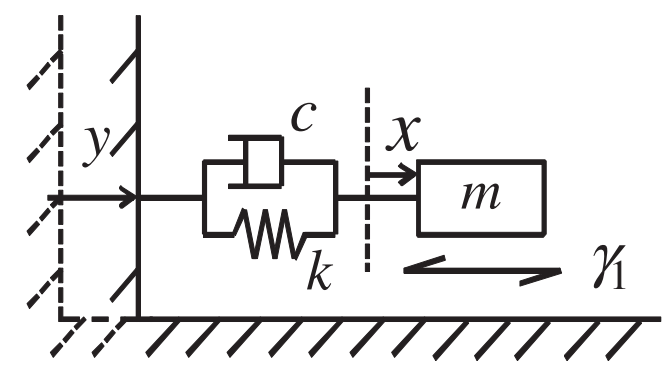

図 1 すべり摩擦を持つ 1 質点系モデル図

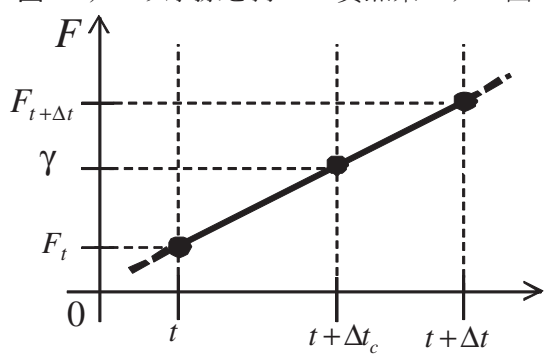

図 2a 質点が静止していて、 $\Delta t$ 間ですべり出寸場合(力)

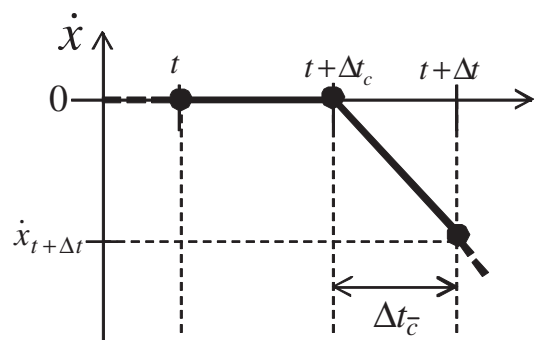

図 $2 b$ 質点が静止していて、 $\Delta t$ 間ですべり出す場合(速度)

\section{3. 新しい提案手法}

本解析手法では、時刻 $t$ から $t+\Delta t$ (刻み時間 $\Delta t$ ) の間で質点が どのような運動状態を示寸か、次の 6 つの場合に分けて解析を行っ た。なお、ここではクーロン摩擦を扱う。

(1) 質点が静止していて、 $\Delta t$ 間ですべり出さない場合

質点は $\Delta t$ 後も静止しているため、次式 (6)となる。

$$
x_{t+\Delta t}=\text { constant }, \quad \dot{x}_{t+\Delta t}=0
$$

(2) 質点が静止していて、 $\Delta t$ 間ですべり出す場合 $F$ を次式(7)で定義する。

$$
F=m \ddot{y}+c \dot{x}+k x
$$

質点がす心゙り出す時刻を $t+\Delta t_{c}$ とすると、図 $2 \mathrm{a}$ のように $\Delta t_{c}$ は以 下の関係式から得られる。

$$
\begin{aligned}
& \gamma_{1}=\frac{\left(F_{t+\Delta t}-F_{t}\right)}{\Delta t} \Delta t_{c}+F_{t} \\
& \Delta t_{c}=\frac{\left(\gamma_{1}-F_{t}\right)}{\left(F_{t+\Delta t}-F_{t}\right)} \Delta t
\end{aligned}
$$

ここで $F_{t+\Delta t}$ は、 $\Delta t$ は小さいので、 $t+\Delta t_{c}$ から $t+\Delta t$ までの質点 の変化は微小と仮定し、 $\dot{x}_{t+\Delta t} \fallingdotseq \dot{x}_{t+\Delta t_{c}}=0 、 x_{t+\Delta t} \fallingdotseq x_{t+\Delta_{c}}=x_{t}$ とおい て、次式で求める。

$$
F_{t+\Delta t}=m \ddot{y}_{t+\Delta t}+k x_{t}
$$

時刻 $t$ から $t+\Delta t_{c}$ 間では、図 $2 \mathrm{~b}$ のように質点は静止している。

$$
x_{t+\Delta t_{c}}=\text { constant }, \quad \dot{x}_{t+\Delta t_{c}}=0
$$

時刻 $t+\Delta t_{c}$ から $t+\Delta t$ 間では、刻み時間を $\Delta t_{\bar{c}} \quad\left(\Delta t_{\bar{c}}=\Delta t-\Delta t_{c}\right)$ と して線形加速度法に基づいた次式(10)で計算する。

$$
\begin{aligned}
& x_{t+\Delta t}=x_{t+\Delta t_{c}}+\dot{x}_{t+\Delta t_{c}} \Delta t_{\bar{c}}+\frac{\ddot{x}_{t+\Delta t_{c}}}{3} \Delta t_{\bar{c}}^{2}+\frac{\ddot{x}_{t+\Delta t}}{6} \Delta t_{\bar{c}}^{2} \\
& \dot{x}_{t+\Delta t}=\dot{x}_{t+\Delta t_{c}}+\frac{\ddot{x}_{t+\Delta t_{c}}}{2} \Delta t_{\bar{c}}+\frac{\ddot{x}_{t+\Delta t}}{2} \Delta t_{\bar{c}} \\
& \ddot{x}_{t+\Delta t}=-\ddot{y}_{t+\Delta t}-\frac{c}{m} \dot{x}_{t+\Delta t}-\frac{k}{m} x_{t+\Delta t}-\frac{\gamma_{1}}{m} \operatorname{sgn}\left(\dot{x}_{t+\Delta t}\right)
\end{aligned}
$$

(3) 質点がす心゙っていて、 $\Delta t$ 間す心゙り続ける場合

時刻 $t$ から $t+\Delta t$ 間を次式(11)で計算する。

$$
\begin{aligned}
& x_{t+\Delta t}=x_{t}+\dot{x}_{t} \Delta t+\frac{\ddot{x}_{t}}{3} \Delta t^{2}+\frac{\ddot{x}_{t+\Delta t}}{6} \Delta t^{2} \\
& \dot{x}_{t+\Delta t}=\dot{x}_{t}+\frac{\ddot{x}_{t}}{2} \Delta t+\frac{\ddot{x}_{t+\Delta t}}{2} \Delta t \\
& \ddot{x}_{t+\Delta t}=-\ddot{y}_{t+\Delta t}-\frac{c}{m} \dot{x}_{t+\Delta t}-\frac{k}{m} x_{t+\Delta t}-\frac{\gamma_{1}}{m} \operatorname{sgn}\left(\dot{x}_{t+\Delta t}\right)
\end{aligned}
$$

(4) 質点がすべっていて、 $\Delta t$ 間で速度の向きが逆転する場合

図 $3 \mathrm{a}$ のように速度の向きが変わる時刻を $t+\Delta t_{c}$ とすると、線形加速 度法の速度の式、

$$
\dot{x}_{t+\Delta t_{c}}=\dot{x}_{t}+\frac{\ddot{x}_{t}}{2} \Delta t_{c}+\frac{\ddot{x}_{t+\Delta t_{c}}}{2} \Delta t_{c}
$$

より、 $\dot{x}_{t+\Delta t_{c}}=0$ とおいて、次式(12)が求まる。

$$
\Delta t_{c}=\frac{-2 \dot{x}_{t}}{\ddot{x}_{t}+\ddot{x}_{t+\Delta t_{c}}}
$$

この $\Delta t_{c}$ は次のように求めている。i )まず、式(11)の $x_{t+\Delta t} 、 \dot{x}_{t+\Delta t}$ の右辺の中の $\ddot{x}_{t+\Delta t}$ に $\ddot{x}_{t}$ を代入し、1 回目の $x_{t+\Delta t} 、 \dot{x}_{t+\Delta t}$ を計算 する。ii)それらを式(11)の $\ddot{x}_{t+\Delta t}$ の右辺に代入して $\ddot{x}_{t+\Delta t}$ を求める。 iii)この $\ddot{x}_{t+\Delta t}$ を式(11)の $x_{t+\Delta t} 、 \dot{x}_{t+\Delta t}$ の $\ddot{x}_{t+\Delta t}$ に代入し、 $x_{t+\Delta t}$ 、 


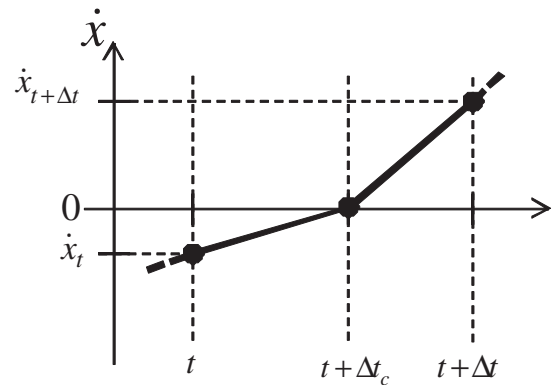

図3a 質点がすべっていて、 $\Delta t$ 間で速度の

向きが正から負になる場合(速度)

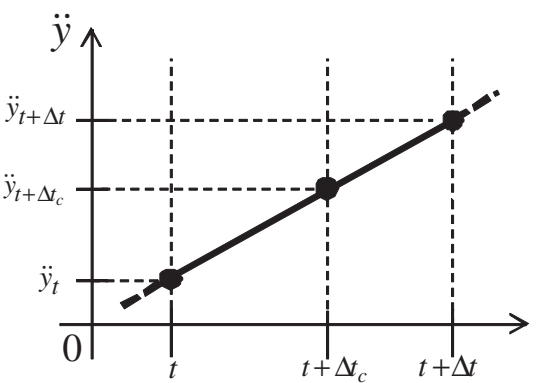

図 3b 質点がすべっていて、 $\Delta t$ 間で速度の

向きが正から負になる場合(入力加速度)

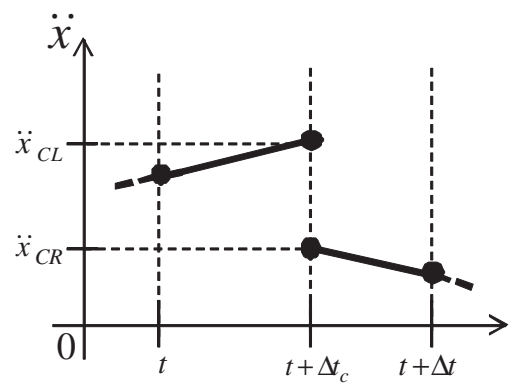

図 3c 質点がす心゙っていて、 $\Delta t$ 間で速度 の向きが正から負になる場合(加速度)

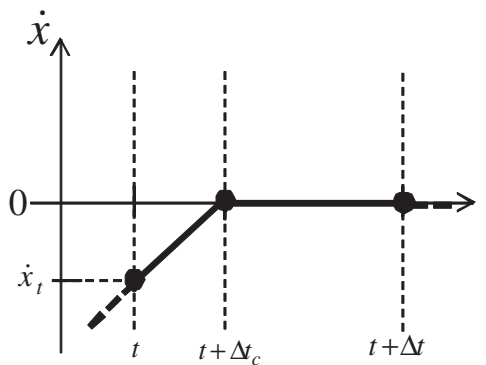

図 4 質点がすべっていて、 $\Delta t$ 間で静止する場合

$\dot{x}_{t+\Delta t}$ を求める。iv)得られた $x_{t+\Delta t} 、 \dot{x}_{t+\Delta t}$ と $\ddot{y}_{t+\Delta t}$ を式(11)の $\ddot{x}_{t+\Delta t}$ の右辺に代入して $\ddot{x}_{t+\Delta t}$ を求める。 $\mathrm{v}$ )ここで $\ddot{x}_{t+\Delta t}$ の収斂の 度合いを判定し、収斂が悪ければ、iii)に行きiii）～v ）の工程を $\ddot{x}_{t+\Delta t}$ が収斂するまで行う。収斂と判断したら vi)へ向かう。vi)収斂した $\ddot{x}_{t+\Delta t}$ を $\ddot{x}_{t+\Delta t_{c}}$ とおいて式(12)より $\Delta t_{c}$ を求める。vii) 得られた $\Delta t_{c}$ から式(13)より $\ddot{y}_{t+\Delta t_{c}}$ を求める。(図 $3 \mathrm{~b}$ )

$$
\ddot{y}_{t+\Delta t_{c}}=\frac{\ddot{y}_{t+\Delta t}-\ddot{y}_{t}}{\Delta t} \Delta t_{c}+\ddot{y}_{t}
$$

viii) vi)で得た $\ddot{x}_{t+\Delta t_{c}} 、 \Delta t_{c}$ 並びに $\ddot{y}_{t+\Delta t}$ を使い、さらに iii) v)ま での $\Delta t$ を $\Delta t_{c}$ とみなし, iii)〜 v)の工程で $\ddot{x}_{t+\Delta t_{c}}$ を求め、 $\ddot{x}_{t+\Delta t_{c}}$ を
式(12)に代入し、 $\Delta t_{c}$ を求める。

時刻 $t+\Delta t_{c}$ の変位、速度は、次式(14) となる。

$$
\begin{aligned}
& x_{t+\Delta t_{c}}=x_{t}+\dot{x}_{t} \Delta t_{c}+\frac{\ddot{x}_{t}}{3} \Delta t_{c}^{2}+\frac{\ddot{x}_{t+\Delta t_{c}}}{6} \Delta t_{c}^{2} \\
& \dot{x}_{t+\Delta t_{c}}=0
\end{aligned}
$$

$t+\Delta t_{c}$ 直前、直後の加速度 $\ddot{x}_{C L} 、 \ddot{x}_{C R}$ は次式(15)、(16)より求まる。

$$
\begin{gathered}
\ddot{x}_{C L}=-\ddot{y}_{t+\Delta t_{c}}-\frac{c}{m} \dot{x}_{t+\Delta t_{c}}-\frac{k}{m} x_{t+\Delta t_{c}}-\frac{\gamma_{1}}{m} \operatorname{sgn}\left(\dot{x}_{C L}\right) \\
\ddot{x}_{C R}=-\ddot{y}_{t+\Delta t_{c}}-\frac{c}{m} \dot{x}_{t+\Delta t_{c}}-\frac{k}{m} x_{t+\Delta t_{c}}-\frac{\gamma_{1}}{m} \operatorname{sgn}\left(\dot{x}_{C R}\right) \\
\dot{x}_{C L}=0 \pm \varepsilon, \dot{x}_{C R}=0 \mp \varepsilon
\end{gathered}
$$

であり、土符号は符号同順、 $\varepsilon$ は微小量である。式(17)を参考にす れば、 $\dot{x}_{C R}$ と $\dot{x}_{C L}$ は符号が逆になるので、

$$
\operatorname{sgn}\left(\dot{x}_{C R}\right)=-\operatorname{sgn}\left(\dot{x}_{C L}\right)
$$

となる。式(16)から式(15)を差し引いて、式(18)の関係を使えば、次 式(19)が求まる。

$$
\ddot{x}_{C R}=\ddot{x}_{C L}+2 \frac{\gamma_{1}}{m} \operatorname{sgn}\left(\dot{x}_{C L}\right)
$$

次に、時刻 $t+\Delta t_{c}$ から $t+\Delta t$ 間を計算する。 $\Delta t_{\bar{c}}\left(\Delta t_{\bar{c}}=\Delta t-\Delta t_{c}\right)$ を用いて時刻 $t+\Delta t_{c}$ から $t+\Delta t$ 間の変位、速度、加速度を式(14)の 変位、速度、式(19)の加速度を用いて次式(20)より求める。

$$
\begin{aligned}
& x_{t+\Delta t}=x_{t+\Delta t_{c}}+\dot{x}_{t+\Delta t_{c}} \Delta t_{\bar{c}}+\frac{\ddot{x}_{C R}}{3} \Delta t_{\bar{c}}^{2}+\frac{\ddot{x}_{t+\Delta t}}{6} \Delta t_{\bar{c}}^{2} \\
& \dot{x}_{t+\Delta t}=\dot{x}_{t+\Delta t_{c}}+\frac{\ddot{x}_{C R}}{2} \Delta t_{\bar{c}}+\frac{\ddot{x}_{t+\Delta t}}{2} \Delta t_{\bar{c}} \\
& \ddot{x}_{t+\Delta t}=-\ddot{y}_{t+\Delta t}-\frac{c}{m} \dot{x}_{t+\Delta t}-\frac{k}{m} x_{t+\Delta t}-\frac{\gamma_{1}}{m} \operatorname{sgn}\left(\dot{x}_{t+\Delta t}\right)
\end{aligned}
$$

(5) 質点がすべっていて、 $\Delta t$ 間で静止する場合

質点が静止する時刻を $t+\Delta t_{c}$ とすると式(12)を用いて、時刻 $t$ から $t+\Delta t_{c}$ 間を次式(21)で計算する。（図 4$)$

$$
\begin{aligned}
& x_{t+\Delta t_{c}}=x_{t}+\dot{x}_{t} \Delta t_{c}+\frac{\ddot{x}_{t}}{3} \Delta t_{c}^{2}+\frac{\ddot{x}_{t+\Delta t_{c}}}{6} \Delta t_{c}^{2} \\
& \dot{x}_{t+\Delta t_{c}}=0, \quad \ddot{x}_{t+\Delta t_{c}}=0
\end{aligned}
$$

時刻 $t+\Delta t$ から $t+\Delta t$ 間を次式(22)で計算する。

$$
x_{t+\Delta t}=\text { constant } \quad, \quad \dot{x}_{t+\Delta t}=0 \quad, \quad \ddot{x}_{t+\Delta t}=0
$$

(6) 質点がすべっていて、 $\Delta t$ 間で静止して再びすべり出す場合

(2)と (5)を合わせたものである。質点が静止する時刻を $t+\Delta t_{c}$ とす ると式(12)を用いて、時刻 $t$ から $t+\Delta t_{c}$ 間を次式(23)で計算する。

$$
\begin{aligned}
& x_{t+\Delta t_{c}}=x_{t}+\dot{x}_{t} \Delta t_{c}+\frac{\ddot{x}_{t}}{3} \Delta t_{c}^{2}+\frac{\ddot{x}_{t+\Delta t_{c}}}{6} \Delta t_{c}^{2} \\
& \dot{x}_{t+\Delta t_{c}}=0
\end{aligned}
$$

次に、式(7)より求めた $F$ と等しくなる時刻 $t+\Delta t_{c^{\prime}}$ ，を次式(24)で計算する。 また刻多時間を $\Delta t_{\bar{c}}\left(\Delta t_{\bar{c}}=\Delta t-\Delta t_{c}\right)$ とする。(図 $\left.5 \mathrm{a}\right)$

$$
\begin{aligned}
\gamma_{1} & =\frac{\left(F_{t+\Delta t}-F_{t+\Delta t_{c}}\right)}{\Delta t_{\bar{c}}} \Delta t_{c^{\prime}}+F_{t+\Delta t_{c}} \\
\Delta t_{c^{\prime}} & =\frac{\left(\gamma_{1}-F_{t+\Delta t_{c}}\right)}{\left(F_{t+\Delta t}-F_{t+\Delta t_{c}}\right)} \Delta t_{\bar{c}}
\end{aligned}
$$

時刻 $t+\Delta t_{c}$ から $t+\Delta t_{c^{\prime}}$ 間では、質点は静止している。(図 $5 \mathrm{~b}$ )

$$
x_{t+\Delta t_{c^{\prime}}}=\text { constant } \quad, \quad \dot{x}_{t+\Delta t_{c^{\prime}}}=0
$$




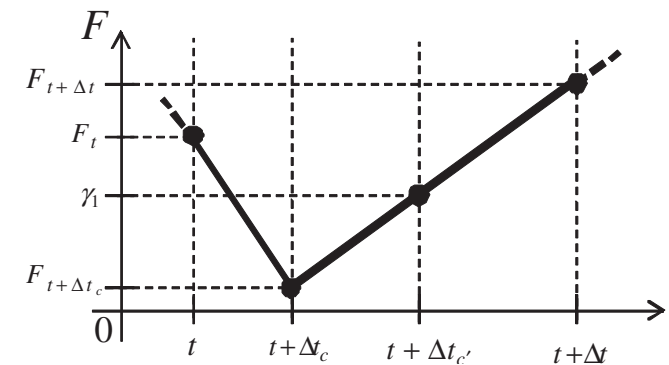

図 $5 \mathrm{a}$ 質点がす心゙っていて、 $\Delta t$ 間で静止して 再びすべり出す場合(力)

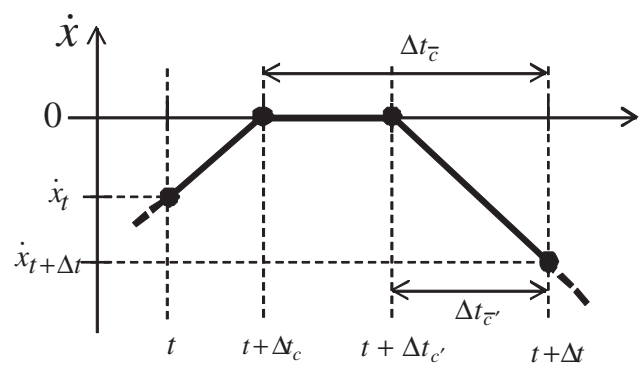

図 $5 \mathrm{~b}$ 質点がすべっていて、 $\Delta t$ 間で静止して

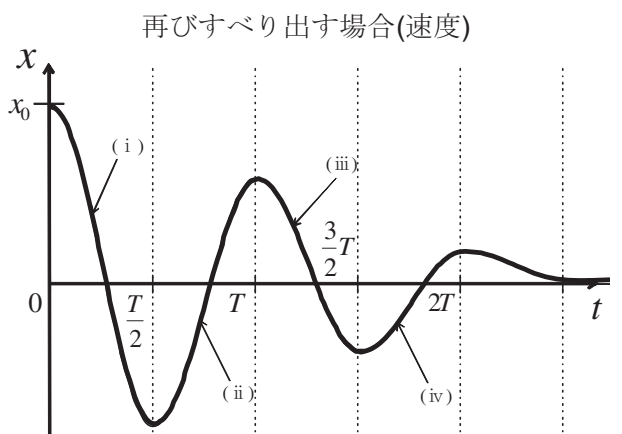

図 6 すべり摩擦を持つ 1 質点系の自由振動波形

時刻 $t+\Delta t_{c^{\prime}}$ から $t+\Delta t$ 間では、刻み時間を $\Delta t_{\bar{c}},\left(\Delta t_{\bar{c}^{\prime}}=\Delta t-\Delta t_{c^{\prime}}\right)$ と して次式(26)で計算する。

$$
\left.\begin{array}{l}
x_{t+\Delta t}=x_{t+\Delta t_{c^{\prime}}}+\dot{x}_{t+\Delta t_{c^{\prime}}} \Delta t_{\bar{c}^{\prime}}+\frac{\ddot{x}_{t+\Delta t_{c^{\prime}}}}{3} \Delta t_{\bar{c}^{\prime}}^{2}+\frac{\ddot{x}_{t+\Delta t}}{6} \Delta t_{\bar{c}^{\prime}}^{2} \\
\dot{x}_{t+\Delta t}=\dot{x}_{t+\Delta t_{c^{\prime}}}+\frac{\ddot{x}_{t+\Delta t_{c^{\prime}}}}{2} \Delta t_{\bar{c}^{\prime}}+\frac{\ddot{x}_{t+\Delta t}}{2} \Delta t_{\bar{c}^{\prime}} \\
\ddot{x}_{t+\Delta t}=-\ddot{y}_{t+\Delta t}-\frac{c}{m} \dot{x}_{t+\Delta t}-\frac{k}{m} x_{t+\Delta t}-\frac{\gamma_{1}}{m} \operatorname{sgn}\left(\dot{x}_{t+\Delta t}\right)
\end{array}\right\}
$$

\section{4. 他手法}

3 章で提案した手法は、 $\Delta t$ 間で運動状態を判定し、 $\Delta t$ 在求めて 計算精度を上げる手法である。一方、他手法は線形加速度法を用い るが、例えば式(12)のように $\Delta t_{c}$ を求めない。計算精度を上げるた めには刻み時間 $\Delta t$ を小さくする手法である(図 11 参照)。

\section{5. 減衰係数がない場合で、すべり摩擦を持つ 1 質点系モデルの理論} 解 ${ }^{8)}$, 9)

\section{1. 外力がない場合の理論解 (自由振動)}

すべり摩擦を持つ 1 質点系に初期変位(初速度は $0.0[\mathrm{~m} / \mathrm{s}]$ )を与え て、自由振動させたときの理論式を次式に示す。

$x_{0}>0$ のとき

$$
x(t)=\left\{x_{0}-(2 n+1) x_{f}\right\} \cos \omega_{0} t+(-1)^{n} x_{f}
$$

$$
\frac{n}{2} T<t<\frac{n+1}{2} T(n=0,1,2 \ldots)
$$

( $x_{0}$ : 初期変位, $\omega_{0}$ : 固有角振動数, $x_{f}=\frac{\gamma_{1}}{k}, T$ : 周期 $)$ すべり、静止の判定は応答速度が 0 の時に、以下の式を満たす とき質点はすべり、それ以外は静止とする。

$$
|x|>x_{f}
$$

一例として、図 6 に示す寸べり摩擦を持つ 1 質点系の自由振動 波形に対する理論式を半周期ごとに示す。ちなみに初期変位 $x_{0}$ は 正である。

（i ） $0 \leqq t \leqq \frac{T}{2}$ のとき

$$
x(t)=\left(x_{0}-x_{f}\right) \cos \omega_{0} t+x_{f}
$$

(ii ) $\frac{T}{2} \leqq t \leqq T$ のとき

$$
x(t)=\left(x_{0}-3 x_{f}\right) \cos \omega_{0} t-x_{f}
$$

(iii) $T \leqq t \leqq \frac{3}{2} T$ のとき

$$
x(t)=\left(x_{0}-5 x_{f}\right) \cos \omega_{0} t+x_{f}
$$

(iv) $\frac{3}{2} T \leqq t \leqq 2 T$ のとき

$$
x(t)=\left(x_{0}-7 x_{f}\right) \cos \omega_{0} t-x_{f}
$$

\section{2. 外カとして正弦波を入カした場合の理論解 ${ }^{10)}$}

すべり摩擦を持つ 1 質点系に正弦波 $(\ddot{y}=A \sin \omega t$ ) を入力した場合 の一般解は、式(2)より次式が求まる。

$$
x(t)=B_{1} \sin \omega_{0} t+B_{2} \cos \omega_{0} t-\frac{A}{\omega_{0}^{2}-\omega^{2}} \sin \omega t-\operatorname{sgn}(\dot{x}(t)) x_{f}
$$

[ $A$ : 最大加速度振幅, $\omega$ : 入力の角振動数, $B_{1}, B_{2}$ : 未定係数] ここで、質点が動き出す時刻を $t_{0}$ とすると、初期条件は $t=t_{0} 、 x=x_{0}$, $\dot{x}=0$ として、式(33)から次式となる。

$$
\begin{aligned}
x(t)= & \frac{A}{\omega_{0}^{2}-\omega^{2}}\left\{\sin \omega t_{0} \cos \omega_{0}\left(t-t_{0}\right)\right. \\
\left.+\frac{\omega}{\omega_{0}} \cos \omega_{0} \sin \omega_{0}\left(t-t_{0}\right)\right\} & +\left\{x_{0}+\operatorname{sgn}(\dot{x}(t)) x_{f}\right\} \cos \omega_{0}\left(t-t_{0}\right) \\
& -\frac{A}{\omega_{0}^{2}-\omega^{2}} \sin \omega t-\operatorname{sgn}(\dot{x}(t)) x_{f}
\end{aligned}
$$

質点の寸べり、静止の判定は、応答速度が 0 の時に、式(5)を満た すとき質点はすべり、それ以外は静止とする。この質点が折り返す 時刻 $t_{1}$ 、その時の変位を $x_{1}$ とすると、 $t=t_{1} 、 x=x_{1} 、 \dot{x}=0$ より再度、 式(33)より式(34)の $t_{0}$ を $t_{1}$ として求める。質点が折り返す度にこの 作業を繰り返す。

\section{6. すべり摩擦を持つ 2 質点系について}

2 章、3 章で記述したすべり摩擦を持つ 1 質点系の運動方程式を 拡張し図 7 に示すような 2 質点系のモデルについて述べる。本モデ ルは、 1 層目と地盤との間に摩擦面があり、2 層目と 1 層目、及び 1 層目と地盤には、線形の特性を持つバネ、速度に比例する粘性抵抗 が接続されている。本モデルに強制外力が加わる場合の運動方程式 を次式に示す。

（ I ）すべりが生じていない場合

$$
x_{1}=\text { constant } \quad, \quad \dot{x}_{1}=0
$$

（II）す心゙りが生じている場合

$$
m_{1}\left(\ddot{x}_{1}+\ddot{y}\right)+c_{1} \dot{x}_{1}+k_{1} x_{1}-c_{2}\left(\dot{x}_{2}-\dot{x}_{1}\right)-k_{2}\left(x_{2}-x_{1}\right)+\gamma_{2} \operatorname{sgn}\left(\dot{x}_{1}\right)=0
$$




$$
\left.\begin{array}{c}
m_{2}\left(\ddot{x}_{2}+\ddot{y}\right)+c_{2}\left(\dot{x}_{2}-\dot{x}_{1}\right)+k_{2}\left(x_{2}-x_{1}\right)=0 \\
\gamma_{2}=\mu\left(m_{1}+m_{2}\right) g \\
\dot{x}_{1}>0 \rightarrow \operatorname{sgn}\left(\dot{x}_{1}\right)=+1 \\
\dot{x}_{1}<0 \rightarrow \operatorname{sgn}\left(\dot{x}_{1}\right)=-1
\end{array}\right\}
$$

（ I ）、（II）の切りかえ条件は、応答速度が 0 の時に、以下の式を満た すとき質点はすべり、それ以外は静止とする。

$$
\left|m_{1} \ddot{y}+c_{1} \dot{x}_{1}+k_{1} x_{1}-c_{2}\left(\dot{x}_{2}-\dot{x}_{1}\right)-k_{2}\left(x_{2}-x_{1}\right)\right|>\gamma_{2}
$$

$\left(x_{1}: 1\right.$ 層目の相対変位, $x_{2}: 2$ 層目の相対変位, $\dot{x}_{1}: 1$ 層目の相対 速度， $\dot{x}_{2}: 2$ 層目の相対速度， $\ddot{x}_{1}: 1$ 層目の相対加速度， $\ddot{x}_{2}: 2$ 層目の相対加速度 $m_{1}: 1$ 層目の質量, $m_{2}: 2$ 層目の質量, $c_{1}: 1$ 層目の減衰係数, $c_{2}: 2$ 層目の減衰係数, $k_{1}: 1$ 層目のば利剛性, $k_{2}: 2$ 層目のばね剛性, $\gamma_{2}:$ クーロン摩擦力

\section{2 質点非線形モデル}

上部 2 層目を非線形の構造物 11),12) (倒立した円筒容器構造)、下部 1 層目をすべり摩擦とした系に正弦波を入力した場合の非線形振動 応答解析を行った。上部 2 層目構造物の非線形振動解析には、応答 周波数と振幅の変化に合わせて係数 $\alpha 、 k$ が変化するべき関数型復 元力モデル 11),12)(図 8)を用いた等価線形化モデル 13)を適用寸る。そ して下部 1 層目すべり摩擦には、今回の提案手法を適用する。

クーロン摩擦 1 質点系の各種地震応答解析 ${ }^{4), 7}$ に関寸る応答解析 結果を参照すると、そのときの地震波加速度記録に対して, 例えば 家の中の床免震のような場合, 免震構造の応答值の最小值は固有周 期 $T_{1}=3 \sim 4[\mathrm{~s}] ， \mu=0.05 \sim 0.1$ のときに求められている。本論でも 地盤と容器とを結合するばね剛性、減衰係数は、固有周期を $3[\mathrm{~s}]$ と なるようにして次式を用いている。

$$
\begin{gathered}
k_{1}=\frac{4 \pi^{2}\left(m_{1}+m_{2}\right)}{T^{2}} \\
c_{1}=2 h_{1}\left(m_{1}+m_{2}\right) \sqrt{\frac{k_{1}}{\left(m_{1}+m_{2}\right)}}
\end{gathered}
$$

\begin{tabular}{|c|c|c|c|c|}
\hline & 質量 [kg] & $\begin{array}{l}\text { 減衰係数 } \\
{[\mathrm{N} \cdot \mathrm{s} / \mathrm{m}]}\end{array}$ & $\begin{array}{c}\text { ば衫剛性 } \\
{[\mathrm{N} / \mathrm{m}]}\end{array}$ & 摩擦係数 \\
\hline $\begin{array}{c}1 \text { 質点系 } \\
\text { (外力無し) }\end{array}$ & 10.00 & 0.00 & 196.00 & 0.05 \\
\hline $\begin{array}{c}1 \text { 質点系 } \\
\text { (外力あり) }\end{array}$ & 10.00 & 0.00 & 196.00 & 0.10 \\
\hline $\begin{array}{c}2 \text { 質点系 } \\
1 \text { 層目 }\end{array}$ & 1.00 & 23.14 & 48.25 & 0.10 \\
\hline $\begin{array}{c}2 \text { 質点系 } \\
2 \text { 層目 }\end{array}$ & 10.00 & 0.00 & 367.75 & - \\
\hline
\end{tabular}

(減衰定数 : $h_{1}=0.05,1$ 層目と 2 層目の質量の比 : $\frac{m_{1}}{m_{2}}=\frac{1}{10}, \mu=0.5$ )

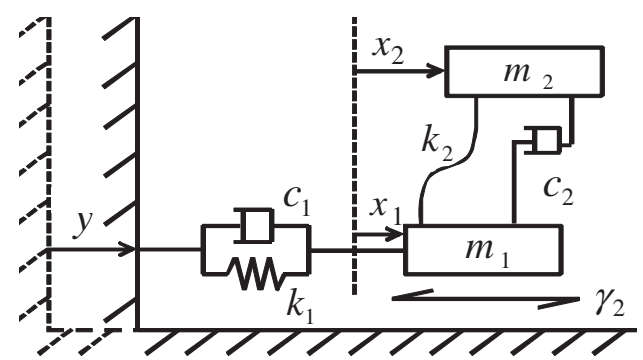

図 7 すべり摩擦を持つ 2 質点系モデル図

表 1 各モデルにおける諸量

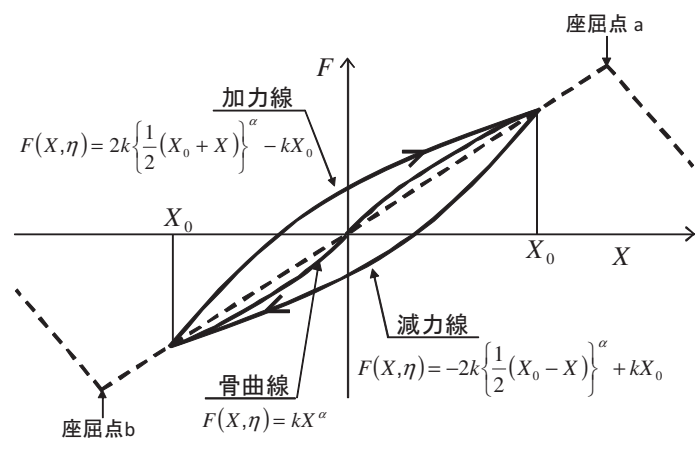

図 8 ベき関数型復元力モデル

(本論のすべり摩擦系の解析では、座屈点 $\mathrm{a} 、 \mathrm{~b}$ を超えない)

また、2 層目非線形構造物の質量 $m_{2}$ は、文献 $\left.{ }^{2}\right)$ による容器構造の 質量を用いている。減衰係数 $c_{2}$ 、ば祇剛性 $k_{2}$ に関しては図 8 のべ き関数型復元力モデルを用いて、応答速度の符号が変化した時に逐 次、等価な減衰係数 $c_{2}$ 、等価なばね剛性 $k_{2}$ に置きかえて計算する 13)。図 8 の式中のモデルの形状を決定するパラメータ $\alpha 、 k$ は、文 献 11),12)の実験結果から決定している。今回の解析では入力の周波数 が 6.0[Hz]で、 1 層目がすべっている状態で 2 層目非線形系は、定常 状態において $\alpha=0.22 \sim 0.23 、 k=1.90 \sim 1.91$ の間で変化している。 また $X$ は無次元化された変位、 $X_{0}$ は無次元化された履歴復元力の 最大変位、 $\eta$ は無次元化された応答周波数である ${ }^{11)}, 12$ 。

\section{8. 解析結果}

\section{1. すべり摩擦を持つ 1 質点系の自由振動時における理論解と数}

\section{值解の比較}

速度が 0 で発生する応答加速度の不連続をより正確に計算するた めに提案した解析手法の妥当性を検証する。すべり摩擦を持つ質点 (図 1)に初期変位を与えたときの自由振動時における理論解(5 章) と 提案した新しい手法による数值解(3 章)、そして他手法による数值解 (4 章)を比較した。このときのモデルの諸量は表 1 に示し、本手法 と他手法の刻み時間は、ともに $0.01[\mathrm{~s}]$ とて計算している。初期変 位 $0.2[\mathrm{~m}]$ としたときの理論解と数值解における応答変位波形(図 9) では、提案手法は理論解に対し、精度よく応答解析結果を得ること ができた。また、応答加速度の不連続は応答加速度波形(図 10、図 11)から分かるように、提案手法は理論解に対してよく一致している. 一方、他手法はかなり粗い近似になっていることが図 11 から分か る。この粗さは他手法の刻み時間を $0.0001[\mathrm{~s}]$ とすると、かなり理論 解に一致してくる。

\section{2. すべり摩擦を持つ 1 質点系に強制外力を与えたときの他手法 と本手法の比較、及び理論解の比較}

まず、図 1 のモデルに正弦波を与えた場合の本手法による応答解 析結果を理論解、他手法による数值解と比較した。ここで、モデル の諸量は表 1 に示し、本手法と他手法の刻み時間はともに 0.01[s] としている。図 12 に示すような最大加速度振幅 500 [gal]、周波数 $5.0[\mathrm{~Hz}]$ の正弦波を入力した場合の相対応答変位波形、絶対応答加 速度波形を図 13、図 14 に示す。理論解に対して本手法による解析 結果は精度良く求められていることが分かる。一方他手法は、理論 解に対してかなりずれが生じている。次に、図 15 に示寸実地震波 


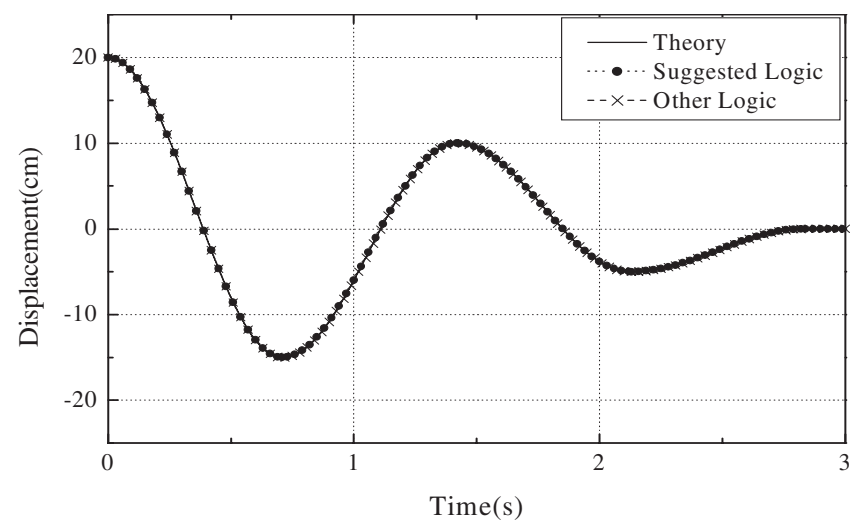

図 9 応答変位波形 (質点を自由振動させたとき)

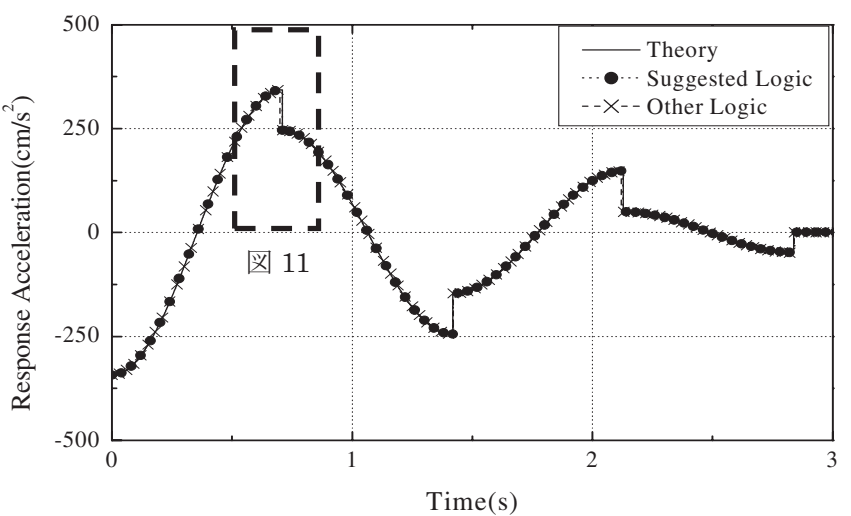

図 10 応答加速度波形 (質点を自由振動させたとき)

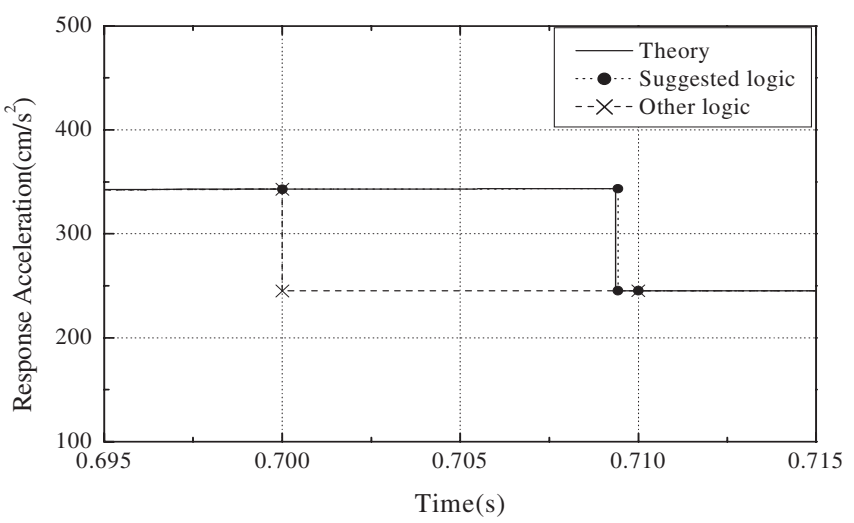

図 11 応答加速度波形図 10 の拡大図 (0.695[s]から 0.715[s]付近)

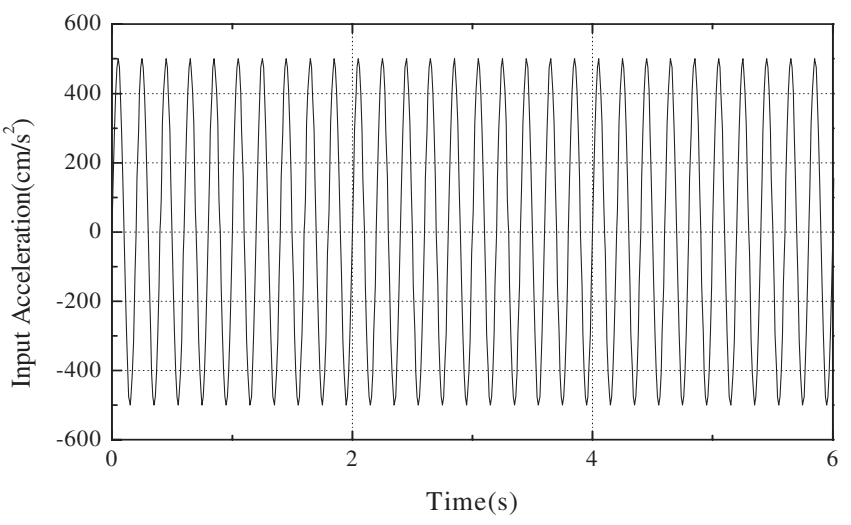

図 12 正弦波入力加速度波形 $(5.0[\mathrm{~Hz}])$

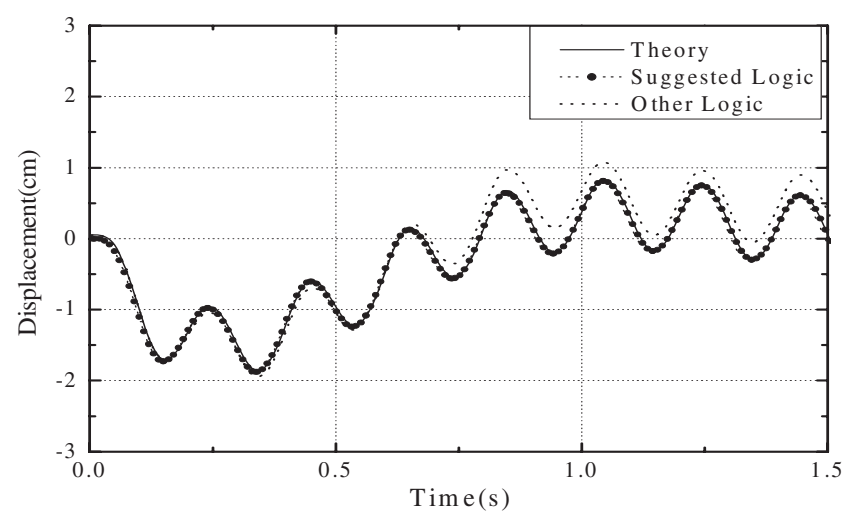

図 13 相対応答変位波形 $(5.0[\mathrm{~Hz}])$

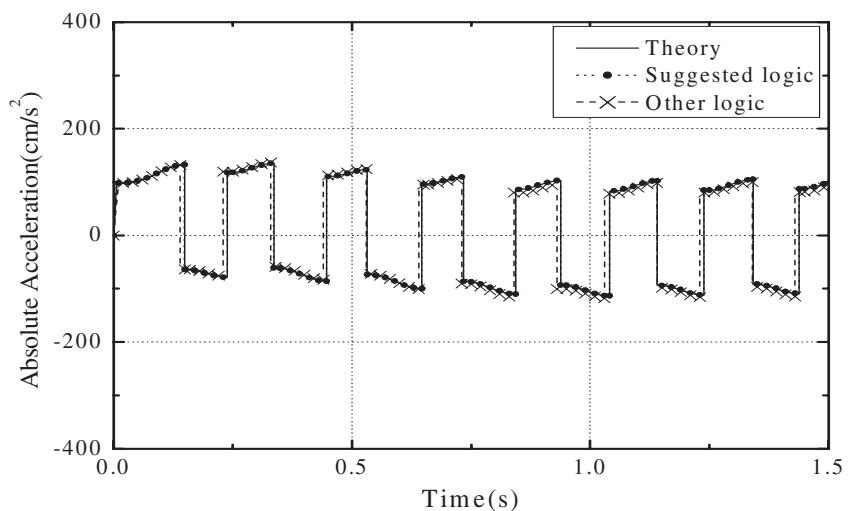

図 14 絶対応答加速度波形 $(5.0[\mathrm{~Hz}])$

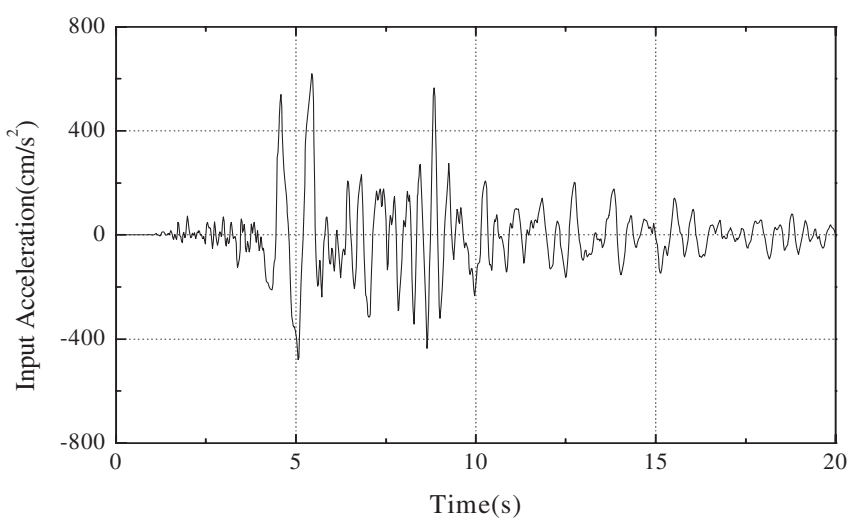

図 15 地震波入力加速度波形 (JMA Kobe 1995[EW])

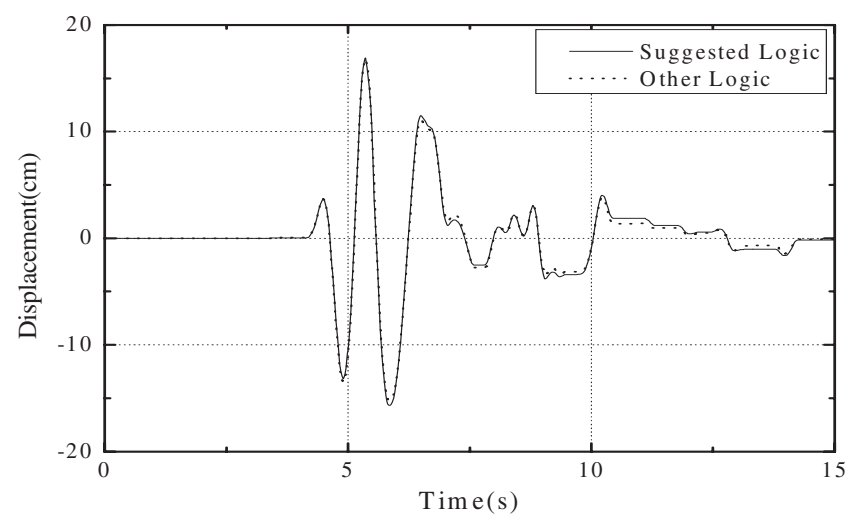

図 16 相対応答変位波形 (JMA Kobe 1995[EW]) 


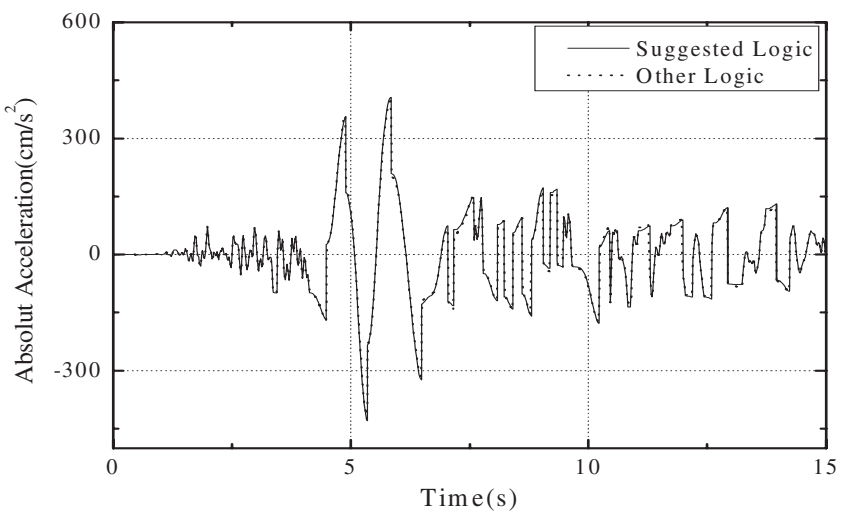

図 17 絶対応答加速度波形 (JMA Kobe 1995[EW])

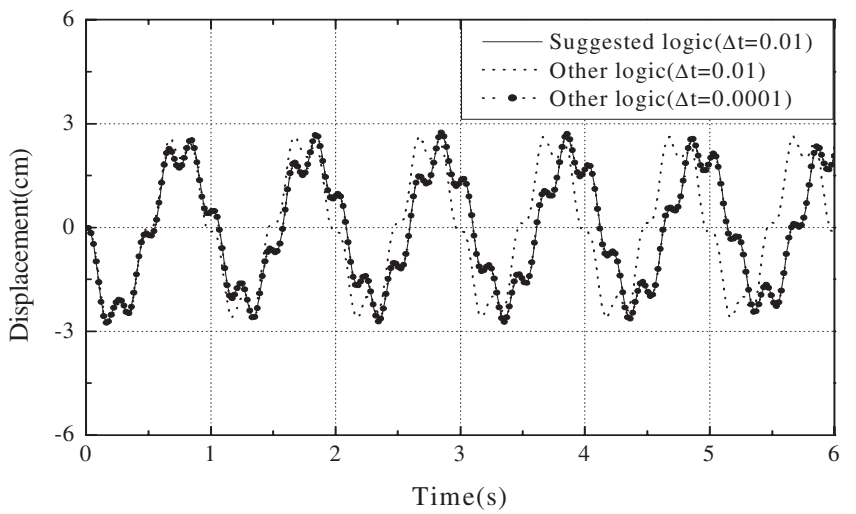

図 18 相対応答変位波形 (2 層目、正弦波)

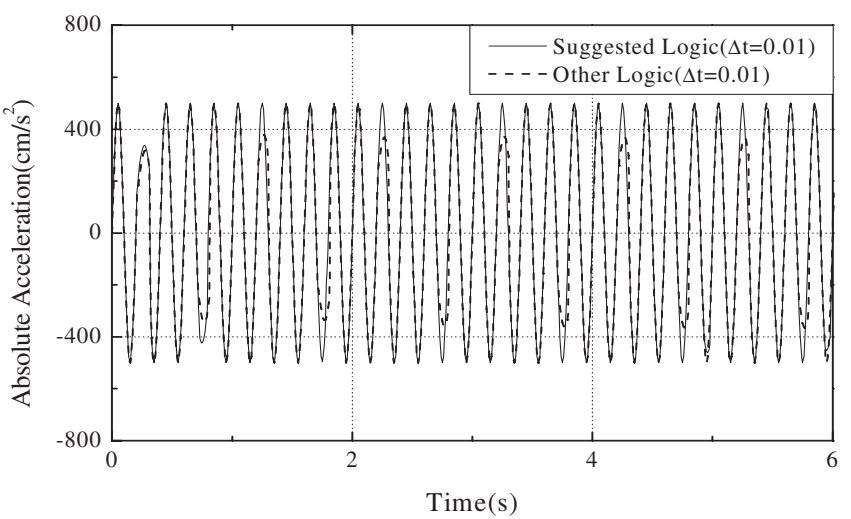

図 19 絶対応答加速度波形 (1 層目、正弦波)

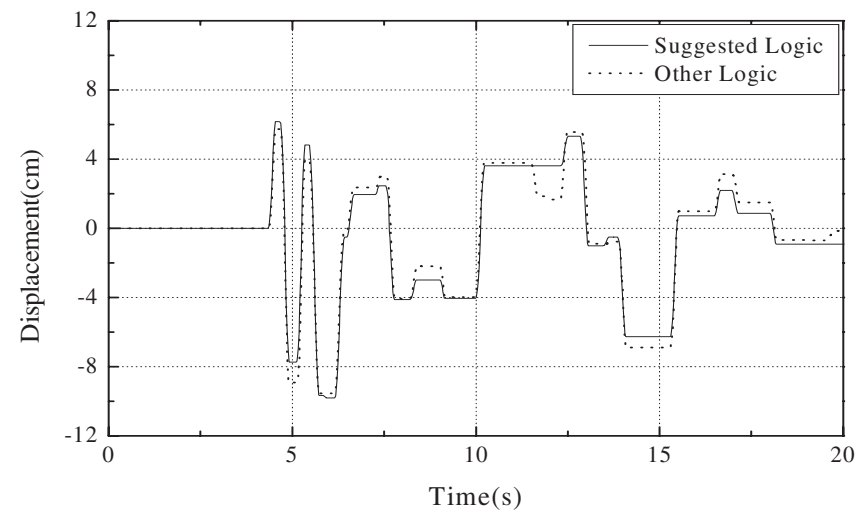

図 20 相対応答変位波形 (1 層目、JMA Kobe 1995[EW])

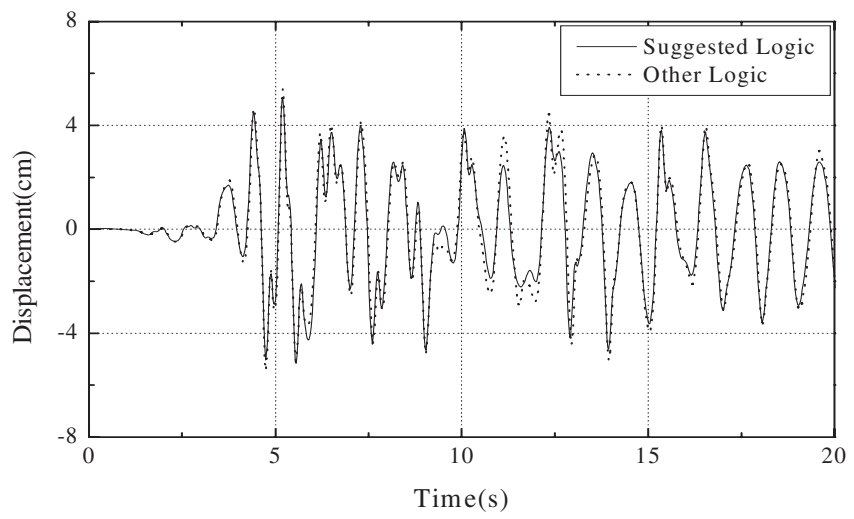

図 21 相対応答変位波形 (2 層目、JMA Kobe 1995[EW])

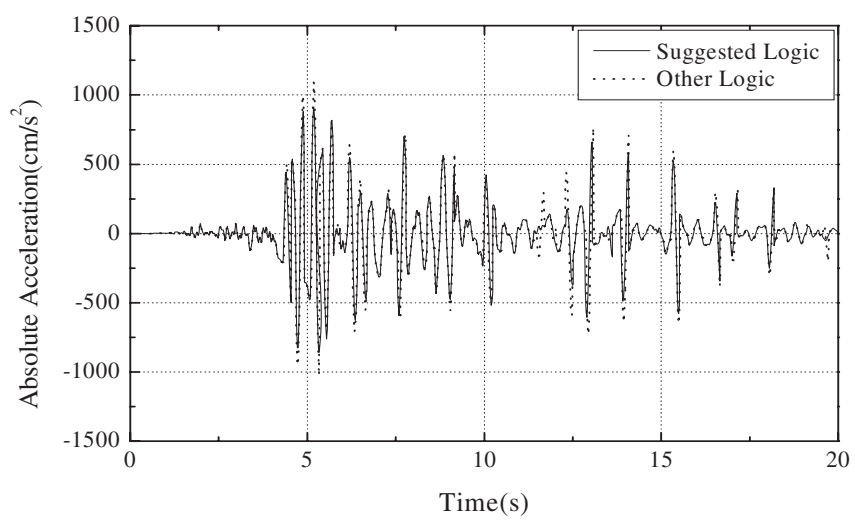

図 22 絶対応答加速度波形 (1 層目、JMA Kobe 1995[EW])

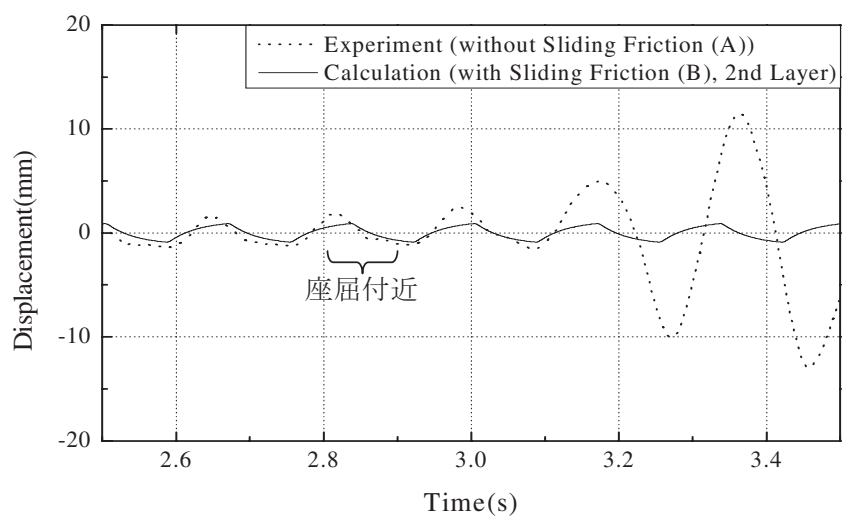

図 23 (容器) 相対応答変位波形 (2 層目応答、正弦波入力、 $\mu=0.5$ )

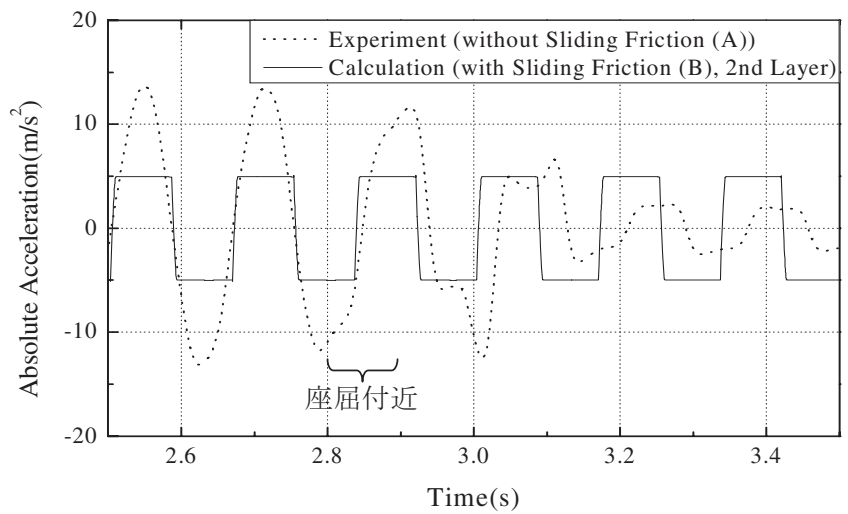

図 24 (容器) 絶対応答加速度波形 ( 2 層目応答、正弦波入力、 $\mu=0.5$ ) 
(JAM Kobe EW 方向、最大加速度 619[gal]) を入力した場合の本 手法、他手法による数值解を比較した。得られた相対応答変位波形、 絶対応答加速度波形を図 16、図 17 に示す。他手法と本手法の間に は多少のずれが生じていることが分かる。これらのずれは、他手法 の刻み時間を $0.0001[\mathrm{~s}]$ とするとかなり本手法に一致してくる。

\section{3. すべり摩擦を持つ 2 質点線形モデルに強制外カを与えた場合 の他手法と本手法の比較}

図 7 の線形モデルに正弦波(図 12)を入力した場合の解析、及び実 地震波(図 15)を入力した場合の解析を行った。モデルの諸量は表 1 に示し、刻み時間を本手法、他手法とも $0.01[\mathrm{~s}]$ として計算している (比較のため、2 層目絶対応答加速度(図 18)のみ他手法における刻み 時間 0.0001 秒の解析結果を載せている)。

2 質点系の正弦波入力に対寸る 2 層目相対応答変位、 1 層目絶対 応答加速度(図 18 、図 19)、地震波入力に対する 1 層目相対応答变位、 2 層目相対応答变位、1 層目絶対応答加速度(図 20、図 21、図 22) の解析結果は、本手法と他手法ではかなりのずれが生じている。し かし、図 18 のように、他手法の刻み時間を $0.0001[\mathrm{~s}]$ とすると、本 手法と一致してくることが分かる。

\section{4. 上部に非線形の構造物、下部にすべり摩擦を持つ系の非線形振 動解析}

今回提案した手法の発展性と、下部にす心゙り摩擦を持つ系が強制 外力に対し応答が抑えられていることを示寸ために、文献 11),12)に示 す正弦波入力に対するすべり摩擦のない容器構造の実測值(A) と今 回計算したすべり摩擦を持つ 2 質点非線形モデルを用いた解析結果 (B)を比較した。ここで(B)の上部 2 層目構造物は、べき関数型復元 力モデルを用いた等価線形系解析手法 ${ }^{13)}$ を適用している。入力波形 (入力周波数 $6.0[\mathrm{~Hz}]$ 、入力加速度振幅は時間の経過とともに徐々に 増加させている）に対する(A)、(B)の相対応答変位波形、絶対応答 加速度波形は、最初の入力波形に対して正弦的に応答する。次第に 入力が大きくなると、図 23、図 24 のように $2.8 \sim 2.9$ 秒付近ですべ り摩擦のない(A)では容器の下部が座屈 11$)$ 寸るが、本論のすべり摩 擦を持つ $(\mathrm{B})$ では座屈(座屈点の変位 $1.6[\mathrm{~mm}]$ 、復元力 (せん断 力) $450[\mathrm{~N}])$ に至らず、それ以前にすべり応答をするため、上部も一 定の応答にとどめられていることが分かる。

\section{9. 結論}

本論は、すべり摩擦をもつ振動系において、速度が符号を変える 時に生じる刻み時間内の不連続な応答加速度を正確に計算するため に、3 章の新手法を提案した。初めに、すべり摩擦を持つ 1 質点系 に外力がない場合、ある場合について提案手法を適用し、理論解、 他手法による数值解と比較することで本手法の妥当性を検証した。 さらにこの手法を 2 質点系へ拡張し、下部 1 層目をすべり摩擦系、 上部 2 層目を線形系としたモデルに対しても本手法の妥当性を検証 した。最後に上部を非線形の構造物、下部をすべり摩擦系としたモ デルによる非線形振動解析を行い、本手法の発展性及び、すべり摩 擦を持つ系が強制外力に対し応答が抑えられていることを述べた。 これらのことから以下のことが明らかとなった。

(1) 提案手法は刻み時間内での運動の変化を詳細に解析するため、
他手法 $(\Delta t=0.0001)$ より提案手法 $(\Delta t=0.01)$ の刻み時間の間隔 が大幅に大きくても十分な解析精度を得ることが分かった。

（2）下部 1 層目にすべり摩擦を持つ 2 質点系線形モデルに、本手法 を拡張して解析し、他手法より、計算の刻み時間を 100 倍にしても 同等の解析結果を得ることが確認できた。

（3）下部 1 層目すべり摩擦系、上部 2 層目が非線形の構造物でも本 手法は適用可能であることが確認できた。

他にも本論に検証結果を載せてはいないが、以下のことも確認で きている。

（4）参考文献 7)における摩擦係数変動型の適用事例から、クーロン 摩擦のような摩擦係数一定に限らず、例えば速度依存、または面圧 依存等の摩擦係数変動型でも、本手法は解析可能であり、さらに静 摩擦、動摩擦を区別して解析に発展していくことは可能である。

（5）式(12)を用いれば、線形加速度法のみならず、ルンゲ・クッタ・ ギル法、平均加速度法等でも、本手法を用いた数值解析は可能であ る。

すでに口頭発表論文 1)において概略を示したが、すでに分かって いる理論解等との比較を行い、精度を確認できたこと、また詳細に 解析手法を示したのは今回が初めてである。今後、新手法と他手法 に対する誤差の追究と, 摩擦係数の面圧依存性、速度依存性の解析 例が少ないので、これらの事項を発展していく予定である。

\section{参考文献}

1）松本聡, 北川博, 柴田耕一, 田川健吾, 山田隆夫, 倉部克則：摩擦型免 震に関する研究 その 1 . 解析手法, 日本建築学会大会学術講演梗概集. B, 構造 I, pp.827-828, 1987.10

2）銭志偉，小林淳彦：免震床の地震応答解析，日立金属技報， vol.22, pp.57-60, 2006.1

3）栗田哲, 千葉大輔, 杉村義広: 剛滑り支承免震建物のせん断多質点系 応答解析法, 日本建築学会構造系論文集, 574 号, pp.69-76, 2003.12

4）富田秀之, 山田隆夫, 柴田耕一: すべり摩擦型免震に関する基礎的研究 摩 擦係数, 剛性, 上下動等の影響について, 第 8 回日本地震工学シンポジウ 么, pp.1761-1766, 1990.12

5）山田隆夫, 柴田耕一, 富田秀之: すべり摩擦型免震に関する実験的研究 実 用床免震システムの水平振動実験, 第 8 回日本地震工学シンポジウム, pp.1767-1772, 1990.12

6) 山田隆夫, 富田秀之, 柴田耕一: すべり摩擦型免震に関する基礎的研究 摩 擦材の組合せと動特性，構造工学論文集(Vol.37B), pp165-172，1991.3

7）柴田康弘, 奥岳史, 坂田利文, 岡本修一, 柴田耕一：すべり摩擦型免震 構造の振動応答解析に関する研究 摩擦係数の分布とディンプルすべり支 承上の地震応答解析, 日本建築学会構造系論文集, 第 545 号, pp.63-69 2001.7

8）Lydik S.Jacobsen, Robert S.Ayre: 機械と構造物のための「振動工学」, 丸善, pp.204-206, 1961.5

9) S. P. Timoshenko, D. H. Young, W. Weaver, Jr.原 : 新版「工業振 動学」, コロナ社, pp.167-171, 1977.8

10) Den Hartog, J.P. : Forced Vibrations With Combined Coulomb and Viscous Friction, Trans. ASME APM-53-9, pp.107-115, 1931

11）渡邊健, 柴田耕一: サイロ容器の地震時履歴復元力特性を考慮した非線 形振動応答解析手法に関する研究 変位振幅及び周波数に依存する復元力 特性を持つサイロの振動特性と振動実験, 日本建築学会構造系論文集, 575 号, pp.137-144, 2004.1

12）渡邊健，柴田耕一：サイロ容器の動的履歴特性と換算質量モデルを考慮 した地震応答解析手法に関寸る研究, 日本建築学会構造系論文集, 609 号, pp.49-56, 2006.11

13）柴田耕一, 見坐地一人, 加藤英樹：ゴムの振動特性に関する研究, 日本 機械学会論文集(C), 59 巻 564 号, pp.144-150, 1993.8

（2011年 3 月 9 日原稿受理，2012年 1 月16日採用決定） 